\title{
The Impact of the Sars Cov-2 Pandemic on the Mental Health and Well-Being of Seniors in Social Care Facilities
}

\section{Z. Budayova (Zuzana Budayova)1, L. Ludvigh Cintulova (Lucia Ludvigh Cintulova)²}

${ }^{1}$ Catholic University in Ruzomberok, Faculty of Theology,

Theological Institute, Spisska Kapitula 12, Spisske Podhradie SK.

${ }^{2}$ St. Elisabeth University of Health and Social Sciences,

Faculty of Health and Social Sciences St. Ladislav, Nove Zamky, SK.

\section{E-mail address:}

budayova@gmail.com

\section{Reprint address:}

Zuzana Budayova

Catholic University in Ruzomberok

Faculty of Theology, Institute of Theology

Spisska Kapitula 12

05304 Spisske Podhradie

Slovakia

Source: Clinical Social Work and Health Intervention

Volume: 12

Issue: 3

Pages: 104 - 110

Cited references: 22

\section{Reviewers:}

Mageswaari Rajoo

Bangkok, Thailand

Michael Costello

University of Scranton School of Education, USA

\section{Keywords:}

Covid-19 Pandemic. Seniors. Social Services. Well-being. Mental health.

\section{Publisher:}

International Society of Applied Preventive Medicine i-gap

CSWHI 2021; 12(3): 104 - 110; DOI: 10.22359/cswhi_12_3_18 (C) Clinical Social Work and Health Intervention

\section{Abstract:}

The research study analyses the effects of the Covid-19 pandemic and identifies changes in the life satisfaction of seniors in social services facilities. The research sample consisted of 79 seniors in social services facilities, the sample consisted of ten participants, data collection took place in the period from November 2020 to April 2021, where the method of qualitative research was used in empirical research, through semi-structured interviews to determine the impact of Covid-19 on We collected the data collected by open coding and pointed to those dimensions of the lives of seniors that were most marked by pandemic measures against the spread of Covid-19. 


\section{Introduction}

Due to the rapid growth of COVID-19 cases, many countries have activated emergency plans and developed guidelines to control the disease and defend public health through social distancing interventions, such as suspending cultural and free time activities, travel restrictions and isolation of social care services inside the facility (Santos, 2020). As lockdowns across the world change the day-to-day life of billions of people, the world has had to adapt to the changes. Especially, there are negative impacts on the wellbeing of seniors in the social care centers. The pandemic takes a long time that we can figure out the impact of the coronavirus pandemic on seniors and social services knowing the actual situation.

As of 31 December 2019, a total of 5,452 social service providers were registered in the Slovak Republic, of which 697 (13\%) were semi-established or established by a higher territorial unit and 2,439 (45\%) were non-public providers. Municipalities and social service providers established or established by municipalities have the largest share in the provision of social services (up to $42 \% 2,316$ ), which is mainly due to the municipality's self-governing activity in providing care services, for which 969 "municipal" providers are registered (MPSVaR SR, 2019).

As of 31 Dec. 2018, there were 5,450,421 inhabitants in the Slovak Republic, of which 55,994 recipients $(1.0 \%)$ were provided with services in 1,372 selected types of social services facilities established by the municipality, a higher territorial unit or a non-public provider. In 2018, there were 51,908 places in all monitored types of social services facilities in the Slovak Republic, of which year-round care was provided in 44,406 places $(86 \%)$, weekly care included 615 places $(1 \%)$, day care 6,885 places $(13 \%)$. Of the total number of seats, up to 47,520 seats $(91.5 \%)$ are OPIO facilities with a dependence on social services (MPSVaR SR, 2019).

\section{Impacts of coronavirus SARS CoV-2 on the well-being of the seniors}

The rapid transmission of the severe acute respiratory syndrome corona virus 2 (SARS$\mathrm{CoV}-2$ ) and high death rate could exacerbate the risk of mental health problems and worsen existing psychiatric symptoms further impairing their daily functioning and cognition (Yuan Yang, Wen $\mathrm{Li}, 2020)$.

The COVID-19 pandemic has had huge effects on the daily lives of most individuals in the first half of 2020. Widespread lockdown and preventative measures have isolated individuals, affected the world economy, and limited access to physical and mental healthcare. While these measures may be necessary to minimize the spread of the virus, the negative physical, psychological and social effects are evident (Van Jaarsveld, 2020). The spread of fear, anxiety and even panic influences not only emotional responses to current circumstances, but also leads to a worsening of pre-existing disorders which seniors suffer from (Lima et al., 2020)

Studies have suggested that the psychological effects of this crisis and the prolonged lockdown includes increased stress, anxiety and depression (Sigdel, Bista et al., 2020) the pandemic situation has caused difficulty accessing healthcare resources for non-COVID related problems resulting in higher risk of poor outcomes for those suffering from other diseases (Tam CF, Cheung KS ,2020). The disruption of daily life activities, exercise routines and social therapies, and widely imposed social isolation are all likely to have a large effect on the well-being of elderly people (Rottermund et al., 2021).

Studies have shown that depression in the elderly is linked the subsequent cognitive decline, and risk of Alzheimer's Disease (Sachs-Ericsson et al., 2005), loss of socialization, increased mental strain result in general mental health problems (Van Jaarsveld, 2020), and decreased ability to think positively and find the sense of the life. Long-term isolation can be worsened by the physical limitations put on the movement of individuals outside due to lack of physical activities and exercise that keep mind and body healthy.

The ability to remain in contact with friends and family via online video chat tools may also offer individuals more socializing opportunities to avoid loneliness (Van Jaarsveld, 2020) This is also important for the seniors isolated in the social care centers. Access to, and ability to proficiently use technology is much lower in older populations than in younger adults $(35,36)$. This uneven distribution of technological access and skill is known as the digital divide, or the gray 
digital divide, and researchers have suggested it has continued to increase as the rate of technological innovation speeds up (Paul G, Stegbauer, 2020). This results in a paradoxical situation in which the population most affected by the lockdown is also the population least helped by the digital tools aiming to mitigate the negative effects.

At the same time, face-to-face interactions with friends and family outside the household will reduce to near-zero if social distancing measures are effective. This could cause considerable distress for those unable to visit elderly and vulnerable family and friends outside the home for a period that could last several months. And, these are also the social groups least likely to be able to make use of technological solutions for connecting remotely. Overcoming such digital divides will be critical to reduce the isolation and loneliness that many people in vulnerable groups already suffer and which could be badly exacerbated by COVID-19. The risks of social isolation and loneliness for both physical and mental health are considerable (Klinenberg E., 2016; Pantell et al., 2013; Holt-Lunstad, Smith \& Layton, 2010) and need to be addressed by policy measures, for instance through regular check-ins by social services, civil society and volunteers.

The perception of the measures due to the pandemic is linked with social and psychic trauma including protcovid syndromes. Seniors are more likely to feel depression, suffer from obesity, addictions, pharmacy and they become more dependent on the care of workers in longterm facilities. This may have devastating effect due to isolation of elderly and negative impact on their mental health (Radi, Bundzelová, Olah, Muss, 2021).

Significant pathologies and numerous complications occur in the nervous system. The most dangerous is a stroke especially in the elderly and people with multiple diseases. So-called mild symptoms, which are very important for quality of functioning and quality of life, are: brain fog; concentration; impaired short-term memory; confusion also recorded. These pathologies may persist for a longer period after the infection has passed (Taquet et al. 2021, Šramka et al. 2020) and are often accompanied by anxiety and depression.
Older people have significantly reduced their physical activity in line with recommendations of anti-virus experts and following information from the media. The vast majority have changed their behavior so far, increasing the sedentary lifestyle even more (Rottermund et al., 2012). It can lead to the worse level of well-being as well.

Olah (2016) highlights the key role of the professional workers in the facilities to decrease these negative impacts linked with the coronavirus pandemic by face-to-face communication and using holistic approaches and supporting social work methods. The ability to maintain contacts with the social environment plays a key role in the extent to which the older person is able to cope with sudden changes and better adapt to a new social environment (Tománek, Mátejová, 2019).

\section{Methods}

\section{Objective of research}

The main objective of the research is to determine and identify the extent of the impact of Covid-19 on seniors who have survived pandemic measures in the long-term care facilities for the elderly. The research aim is to identify and analyze changes in the life satisfaction of seniors during the two periods of the coronavirus pandemic in 2020 \& 2021.

The research is based on the following research questions:

RQ1: How did seniors perceive and experience the "first wave" of SARS CoV-2 in AprilMay 2020?

RQ2: How did seniors perceive and experience the "second wave" of SARS CoV-2 in November 2020-April 2021?

RQ3: Which dimensions of senior life have been most affected during the pandemic waves?

The nature of research: Data collection was carried out in the district of Spišská Nová Ves in a residential social facility taking care of the elderly. The facility provides social services for people who have at least IV. level of dependence on social care or for persons who have reached retirement age and need the provision of social services for other serious reasons. The capacity limit of this care center is for 149 seniors in need. The study was carried out in the field in a qualitative way, we used a semi-structured interview 
to gain deeper understanding of the research problem. To know more details on the concept of qualitative research the study is based on the material from authors Neuman (2006), Hendl (2008), Radková \& Ludvigh Cintulová (2018),

Sample: The sample consisted of 79 seniors who were willing and competent to answer the questions due to their medical condition. The determination of the sample size was based on the saturation point, in addition, for its binding and purposefulness. The sample was deliberately selected on the basis of these criteria:

- selection of participants who described their life situation clearly and without embellishments, - taking residential care for more than 3 years, - physical \& mental competences

- the ability to answer questions and to understand them clearly.

We conducted an interview with ten participants $(\mathrm{P})$, whose description shows the following table:

\begin{tabular}{|c|c|c|}
\hline $\begin{array}{c}\text { Interview } \\
\text { No. }\end{array}$ & $\begin{array}{c}\text { First alphabet of } \\
\text { participants name }\end{array}$ & Code \\
\hline 1 & M (woman) & P-M-1 \\
2 & A (man) & P-A-2 \\
3 & D (woman) & P-D-3 \\
4 & F (woman) & P-F-4 \\
5 & F (man) & P-F-5 \\
6 & G (woman) & P-G-6 \\
7 & Z (woman) & P-Z-7 \\
8 & E (man) & P-E-8 \\
9 & J (man) & P-J-9 \\
10 & R (man) & P-R-10 \\
\hline
\end{tabular}

Data collection: We carried out qualitative research through a semi-structured interview concerning the research questions. We recorded the responses on an audio system, used literal transcription, and in the individual sequences and in the interpretation of the results, we present a combination of literal transcription and a summary protocol, according to Hendl (2008).

Data analysis and ethical aspects: The collected information was analyzed by a method of open coding in which we determined in the next step the categories, dimensions resulting from the interpreted interview. We used an alphabetical designation and the interview number as a coding mechanism to ensure the anonymity of the participants. The topic of pandemic measures is a sensitive and often discussed topic from the point of view of seniors. It was therefore necessary to consider some additional issues, which mainly concerned their family members and they were particularly sensitive.

\section{Data analysis: transcription}

Field research through the interviews have shown that the perception of the first wave of SARS CoV-2 and the pandemic situation in older people was surrounded by curiosity and incipient initial fear, while this fear was demonstrably higher for women. The women showed more fear and increased caution and interest in their family and relatives who were in home environments. The participant (P-D-3) stated that:

"... the worst thing is the impossibility to help them and they will not get scared or accidentally ... and how small children will manage it as well ..."

The participant (PZ-7) said that:

"... she has information about the severe course of the disease and the hospitalization of family members and is therefore angry that she cannot visit them and help them in any way "... However, she added that she is " ...no good now that he won't meet them because he's worried about his life ... "

"... I cannot imagine that I should go among the sick ... I would surely die ..." (P-G-6)

Rather, the men expressed interest and concern about how the pandemic and related measures would continue ....

"... Who knows if it will spread more among our old people, or if children and young people will go to the other world ..." (PR-10)

"... 'm glad I'm locked up here so the disease gets to us less ... only if it's brought by nurses ..." (P-A-2)

However, most of the participants managed the situation relatively well ... (P-M-1, P-A-2, PD-3, P-F-5, P-E-8, P-R-10). According to the statement of the participant (PG-6):

"... we walked a lot, because spring came we started doing in the garden ..."

The participants (PF-4, PD-3) said:

"... we also started sunbathing, it was great heat, we just thought it would go faster ...."

"... I was not very worried because our retire- 
ment home protects because we were in isolation ..." (P-F-5)

When asked what form of contact with loved ones and family members they preferred, the participants clearly mentioned the online meeting. Here are some answers:

"... I saw my whole family on the computer three times a week, it was more than if they had to come here under normal circumstances ..." (P-F-4)

(P-M-1) "... at least we learned to do more on the computer and we had no problem ..." (P-E8): "... grandchildren are clever and so they taught me everything via computer, now I can turn on a movie and a video from YouTube ... or whatever it's called ..."

The perception of the second wave of Covid19 disease and the rapidly changing pandemic measures of the Slovak Government was more stressful for seniors also due to contact with the disease that occurred in the facility. The sad and very stressful experience of this period by seniors was also caused by the upcoming Christmas holidays and relatively bad weather. 1):

As the participants stated (PG-6, PZ-7, PM-

"... these were the worst holidays of my life when I see myself with children and grandchildren only on TV ..."

"... No one could come and no one he could not send us anything ... "(PJ-9, PE-8)

"... Also that we had a Christmas tree and all customs preserved ..." (P-A-2, $\mathrm{P}-\mathrm{D}-3)$

"... Neither the priest... nor family... nor anyone... nor anything... could come" (P-E-8)

However, most of the participants agreed that they became more afraid, as Covid-19 was diagnosed in the facility itself:

"... so I didn't know if we could meet that neighbor ..." (P-M-1)

"... After all, we didn't even meet ... everyone lived in their bubble ..." (P-A-2)

"... This was probably the worst period of my life and I survived the war ..." (P-Z-7)

"... I hope this does not happen again ..." (P-R10)

"... They also cancelled my planned operation and medical procedure ... so I started to worry about my life ..." (PF-4)

"... I just hoped that none of my family would die, they could get sick.... but not to die..." (PJ-9)
The research was focused on the analysis of senior life situations and the areas that were the most affected by the pandemic situation (thus the two waves of Covid-19); the participants clearly agreed that there were mental, spiritual and physical aspects and participants were clearly dominated by fear and a sense of danger, expressing:

"... dosed every day only in worse and worse ..." (PJ-9, PF-4, PD-3, PG-6),

"... mainly with negative media information that has been heard everywhere ..." (PR-10, PA2, PG-6, PE-8).

"... I was already annoyed by the negative news on television, I turned it off ..." (P-D-3)

"... I was stressed that everyone was talking only about the crown, we could no longer talk normally, he always stopped talking about illness ..." (P-Z-7)

"... I was angry that we couldn't meet the family, and then when we were locked up at home, it was terrible ..." (P-A-2)

"... I also missed the pastor and Mass ... it's not that on TV ..." (P-G-6)

"... I wanted to go to confess normally but the priest could not come ..." (P-M-1)

"... We were very isolated and it mentally exhausted me ..." (P-J-9)

"... A man to be afraid to die, because there will be no one to bury him, and the family will not even ..." (P-F-5)

\section{Discussion}

The elderly have been and are heavily affected by the pandemic. Based on research results, both waves of Covid-19 and pandemic situations affected the life satisfaction of seniors in social services facilities; negative feelings about pandemic have been increased by the increasing number of days and months of isolation from their families and loved ones.

The most affected areas of life, which the senior participants reported were: the mental health, connected with the increased level of fear; restlessness; even depressive states which would normally require professional help in ordinary and natural conditions. The mental state helped them to overcome contacts with their roommates, but these were interrupted based on the finding of the presence of the disease in the facility itself. However, a new trend has begun to meet loved ones and family members in online virtual space. 
We can thus say that pandemic brought positive aspects in gaining digital skills for seniors who become able to use computer and IT-technology to stay in contact with their outside world. However, it is true that no one and nothing will replace close contact with family, children, grandchildren.

The study results have shown another dimension that has been affected by the pandemic- the spiritual dimension. Participants repeatedly stated dissatisfaction with the absence of the priest, with the impossibility of serving Holy Masses in the social care facility, confessing, and receiving Holy Communion. Seniors expressed fear of their own death, which was conditioned by the absence of family members at the ceremony itself.

Seniors mentioned the dimension of physical health as a third area affected by the pandemic, they have to face negative adverse media information regarding the covid-19 diagnosis, treatment, but also hospitalization itself and the consequences of Covid-19 as they have lack of critical thinking. Seniors feared quarantine measures until complete closure and isolation.

\section{Conclusion}

The pandemic situation and the Covid-19 disease itself required strict adherence to rules that required mental and physical resilience by seniors. However, seniors in social services facilities had to adapt their lives not only in the new environment, but also in new living conditions that have been changed. In the period during isolation, seniors need not only good access to basic life needs, but also to psychological and spiritual care, which lead to overcoming current problems, but also to preventing the emergence of new ones. Mental health promotion is therefore a key factor that determines a senior's ability to stay healthy and achieve well-being. It is therefore necessary to adapt the life of a senior to support emotional \& spiritual as well as mental and physical health.

\section{References}

1. GABRIELLE MARTINS VAN JAARSVELD (2020) The Effects of COVID-19 Among the Elderly Population: A Case for Closing the Digital Divide. Front Psychiatry. 2020; 11: 577427. Published online 2020
Nov 12. doi: 10.3389/fpsyt.2020.577427.

2. HENDL J (2008) Qualitative research: basic theories, methods and applications. (3rd edi.) Praha: Portal, 2008.

3. HOLT-LUNSTAD J, SMITH T, LAYTON J (2010) "Social Relationships and Mortality Risk: A Meta-analytic Review", PLOS Medicine,

Vol. 7/7, https://doi.org/10.1371/journal.pme d.1000316.

4. KLINENBERG E (2016) "Social Isolation, Loneliness, and Living Alone: Identifying the Risks for Public Health", American journal of public health, Vol. 106/5, pp. 786787, https://doi.org/10.2105/AJPH.2016.303 166.

5. LIMA CK, CARVALHO PM, LIMA IA, NUNES JV, SARAIVA JS, DE SOUZA RI, ET AL. (2020). The emotional impact of Coronavirus 2019-nCoV (new Coronavirus disease). Psychiatry Res. 2020; 287:112915.

6. MINISTRY OF LABOR, SOCIAL AFFAIRS AND FAMILY, SR (MPSVaR) (2019) Report on the social situation of the population of the Slovak Republic in 2019. Available at: MINISTERSTVO PRACE, SOCIALNYCH VECI A RODINY (komoraopatrovateliek.sk)

7. NEUMAN J (2006) Quantitative and Qualitative research methods (6th edi.) Pearson Publication India, 2006.

8. OLAH M (2016) Social work in practice. The most common problems of practical social work. Bratislava: Publishing IRIS, 2016.

9. PANTELL M et al. (2013) "Social isolation: a predictor of mortality comparable to traditional clinical risk factors", Am J Public Health, Vol. 103/11, pp. 2056-2062, https:// ajph.aphapublications.org/doi/10.2105/AJPH .2013.301261.

10. PAUL G, STEGBAUER C (2005) Is the digital divide between young and elderly people increasing? First Monday. (2005) Vol.10; doi: 10.5210/fm.v10i10.1286.

11. RADI F, BUNDZELOVA K, OLAH M, MUSS C (2021) Late psychosocial consequencesfrom HIV to Covid. Clin Soc Work and Health Interv.12.2021.2.6-7. 10.22359/ cswhi_12_2_15.

12. RADKOVA L, LUDVIGH CINTULOVA L (2018) Basics of research for students of so- 
cial work and nursing. Bratislava: Protect work a SEU, 2018, p. 135. ISBN 978-80971835-1-6.

13. ROTTERMUND J (2012) What a physical therapist should know about osteoporosis. WSA, Bielsko-Biała, 2012. ISBN 978-8363705-28.

14. ROTTERMUND J, LUDVIGH CINTULOVA L, BUDAYOVAZ (2021). Skeletal muscle damage in Covid-19 disease and its social-psychological aspects. Int J Health New Tech Soc Work 2021;16 (3) ISSN 13369326.

15. SACHS-ERICSSON N, JOINER T, PLANT EA, BLAZER DG (2005) The influence of depression on cognitive decline in community-dwelling elderly persons. Am J Geriatr Psychiatry. 2005 May; 13(5):402-8.

16. SANTOS A FERNANDES (2020) Reflections about the impact of the SARS-COV2/COVID-19 pandemic on mental health. Braz. J. Psychiatr. 42 (3), 2020, https:// doi.org/10.1590/1516-4446-2020-0981

17. SIGDEL A, BISTA A, BHATTARAI N, POON BC, GIRI G, MARQUSEE H, ET AL. (2020) Depression, anxiety and depression-anxiety comorbidity amid covid-19 pandemic: an online survey conducted during lockdown in Nepal. MedRxiv:2020.04.30. 20086926. (2020). 10.1101/2020.04.30. 20086926 .

18. SRAMKA M, SLAVIK J, MASAN J, RUZICKY E (2020) Possible consequences of Covid-19 on the nervous system. Neuro Endocrinol Lett. 2020; 41(4): 166-172. PMID: 33307651 .

19. TAM CF, CHEUNG KS, LAM S, WONG A, YUNG A, SZE M, LAM YM, CHAN C, TSANG TC, TSUI M, TSE HF, SIU CW (2020) Impact of Coronavirus Disease 2019 (COVID-19) Outbreak on ST-Segment-Elevation Myocardial Infarction Care in Hong Kong, China. Circ Cardiovasc Qual Outcomes. 2020 Apr; 13(4): e006631.

20. TAQUET M, GEDDES J R, HUSAIN M, ET AL. (2021) 6-month neurological and psychiatric outcomes in 236379 survivors of COVID-19: a retrospective cohort study using electronic health records. Lancet Psychiatry, 2021; 8: 416-422. https://doi.org/ 10.1016/S2215-0366 (21) 00084-5.
21. TOMANEK P, MATEJOVA A (2019) Family and Current Socialegal Measures for its Members in the Slovak Republic. In Mocna rodzina fundamentemzdrowego społeczeństwa. Krakow: Uniwersytet Papieski Jana Pawła II. w Krakowie, 2019. pp. 69-89. ISBN 978-83-7438-762-0.

22. YUAN YANG, WEN LI, QINGE ZHANG, LING ZHANG, TERIS CHEUNG, YU-TAO XIANG (2020) Mental health services for older adults in China during the COVID-19 outbreak. The Lancet Psychiatry 2020. 7 (4):e19, DOI:https://doi.org/10.1016/S22150366(20)30079-1. 